\title{
IbM WARUNG WISATA SELOREJO: PENINGKATAN KEMAMPUAN PENGELOLA UMKM WARUNG SELOREJO DALAM TATAKELOLA KEUANGAN, PEMASARAN DAN PELAYANAN KONSUMEN
}

\author{
Ernani Hadiyati ${ }^{1^{*}}$, Dwi Orbaningsih ${ }^{2}$, Sugeng Mulyono ${ }^{1}$ \\ ${ }_{1}^{1}$ Program Studi Manajemen, Fakultas Ekonomi dan Bisnis, Universitas Gajayana \\ Jl. Mertojoyo, Merjosari, Malang - Indonesia 65144 \\ ${ }_{2}^{2}$ Program Studi Akuntansi, Fakultas Ekonomi dan Bisnis, Universitas Gajayana \\ Jl. Mertojoyo, Merjosari, Malang - Indonesia 65144 \\ *Penulis korespondensi; Email: ernani_hadiyati@yahoo.com
}

\begin{abstract}
Abstrak: Tujuan pengabdian masyarakat ini adalah meningkatkan kinerja pengelola UMKM, dalam bidang akuntansi, pemasaran dan layanan kepada konsumen. Target kegiatan ini meliputi: peningkatan kemampuan pengelola warung wisata Selorejo dalam tatakelola keuangan yang baik dan layanan kepada konsumen. Sedangkan luaran yang diharapkan berupa jasa pelatihan; modul dan panduan penerapan layanan prima dan pembuatan laporan akuntansi. Metode pelaksanaan menggunakan kombinasi antara pelatihan klasikal, pendampingan dan bantuan dana untuk menstimulir UMKM warung mengimplementasikan materi pelatihan. Hasil pelaksanaan pelatihan menyimpulkan bahwa kinerja pengelola UMKM warung wisata Selorejo di bidang akuntansi dan pelayanan kepada konsumen menunjukkan peningkatan yang signifikan.
\end{abstract}

Kata kunci: Pelatihan, tatakelola keuangan, pemasaran, pelayanan prima dan UMKM

\begin{abstract}
This community service project aims to improve the managerial performance of SMEs on accounting, marketing and services to their consumers. This objective is achieved through brushing up the managerial skills of the manager of the targeted SMEs, especially the financial and marketing skills, as well as their performance in providing consumer services. The expected outcomes are: SMEs' managerial training, module and guidelines for applying accounting principles and providing good consumer services. The method used is the combination of common training principles, assistance and financial support for encouraging the targetted SMEs to implement the materials used in the training. The result of this project indicates that the targeted SMEs, that is, Selorejo tourists' food stall, show improvement in their performance in accounting and consumer service.
\end{abstract}

Keywords: Training, financial management, marketing, better service and SME's

\section{PENDAHULUAN}

Keberadaan Usaha Mikro Kecil dan Menengah (UMKM) mempunyai peranan signifikan dalam menopang pertumbuhan ekonomi nasional maupun regional serta sebagai penyedia lapangan kerja bagi mereka yang berketrampilan rendah. Data Badan Pusat Statistik (BPS) tahun 2009 menunjukkan bahwa secara nasional pada tahun 2008 UMKM mampu menyerap tenaga kerja sebesar 90,9 juta orang atau $97,04 \%$ dari total penyerapan tenaga kerja yang ada. Jumlah ini meningkat sebesar $2,43 \%$ dari jumlah penyerapan tenaga kerja tahun
2007. Menurut Kepala Dinas Koperasi dan UMKM Kabupaten Malang, hingga akhir tahun 2012 jumlah UMKM di Kabupaten Malang sebanyak 273.091 dengan daya serap tenaga kerja sebanyak 469.274 orang (Dinas Komunikasi dan Informatika Propinsi Java Timur, 2013). Data tersebut menunjukkan bahwa sektor ini sudah teruji ketangguhannya dalam menghadapi berbagai kejutan ekonomi dan mempunyai peranan penting sebagai penyedia lapangan kerja dalam skala besar.

Untuk menjamin kelangsungan perkembangannya, UMKM perlu melakukan penataan dan penguatan 
secara komprehensif di bidang pemasaran, layanan pelanggan, akuntansi dan etika bisnis, karena daya dukung SDM yang berkualitas merupakan suatu keharusan untuk optimalisasi kinerja UMKM secara berkelanjutan. Achmadi (1995) dan Tambunan (2008) menegaskan bahwa sampai saat ini UMKM masih dihadapkan pada sejumlah kendala yang berupa keterbatasan akses pasar, pengelolaan bisnis yang masih bersifat tradisional, permodalan, profesionalitas dalam pengelolaan yang rendah, serta kinerja manajerial yang belum optimal. Untuk itu diperlukan langkah nyata untuk membantu UMKM meningkatkan kinerjanya.

Dinas Koperasi, PKM Propinsi Jawa Timur (2002) menjelaskan bahwa optimalisasi kinerja bisnis UMKM memerlukan pendekatan multi dimensi dan sinergis antara institusi pemerintah, swasta maupun perguruan tinggi. Melalui kerja sinergis dengan pemangku kepentingan tersebut diharapkan kinerja pengelola UMKM dapat lebih ditingkatkan kualitasnya.

Upaya mendorong optimalisasi kinerja UMKM, diperlukan peningkatan kualitas SDM demi keberlanjutan usaha ini dalam jangka panjang, baik untuk peningkatan pendapatan masyarakat maupun penanggulangan pengangguran pada tenaga kerja yang tidak memiliki ketrampilan (unskilled labor). Karena itu, kemampuan manajerial dari usaha mikro, yaitu warung, yang terdapat di kawasan wisata Selorejo, Desa Kaumrejo, Kabupaten Malang, perlu untuk lebih ditingkatkan agar warung tersebut tetap dapat bertahan, bahkan berkembang lebih baik, mengingat bahwa ada sebagian penduduk yang menyandarkan kehidupannya pada sektor ini. Gambaran selengkapnya tentang mata pencaharian penduduk dapat dilihat pada gambar diagram 1 berikut.

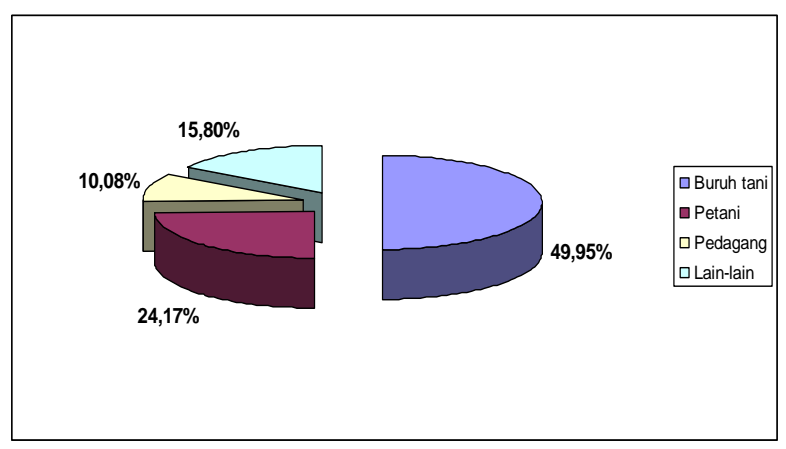

Sumber: Kabupaten Malang dalam angka, diakses 23 Pebruari 2014.

Diagram 1. Mata Pencaharian Penduduk Desa Kaumrejo

Dari data pada diagam 1 menunjukkan bahwa kemampuan daya serap sektor usaha mikro kecil menengah (UMKM) terhadap tenaga kerja lokal ternyata cukup signifikan, karena sebanyak 10,08\% penduduk di desa Kaumrejo dan sekitarnya mengandalkan pekerjaan pada sektor ini.

Sedangkan serapan tenaga kerja pada masingmasing UMKM bervariasi dan tergantung pada skala usaha dan omset penjualannya. Namun demikian, rata-rata usaha warung melibatkan paling sedikit 5 orang. Gambaran selengkapnya tentang serapan tenaga kerja UMKM ditunjukkan dari hasil pra survey terhadap 20 responden sebagaimana disajikan dalam diagram 2 berikut ini.

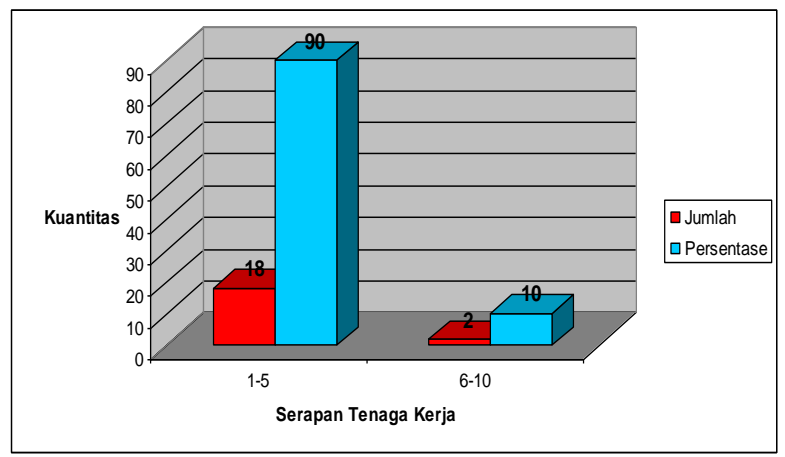

Sumber: Data pra survey, Januari 2014

Diagram 2. Jumlah Serapan Tenaga Kerja

Data pada diagram 2 menunjukkan bahwa sebagian besar UMKM (90\%) melibatkan sejumlah 15 tenaga kerja. Hal ini menunjukkan bahwa keberadaan UMKM sangat mendukung bagi penyediaan lapangan kerja di pedesaan, utamanya bagi tenaga kerja yang mempunyai ketrampilan terbatas dan tingkat pendidikan rendah. Hasil penelusuran lebih dalam menunjukkan bahwa tenaga kerja yang terlibat dalam usaha ini sebagian besar berasal dari penduduk yang berdomisili di desa Kaumrejo dan terdapat pekerja yang berasal dari desa lain di wilayah Kecamatan Ngantang. Dari sisi penyerapan tenaga kerja memang peranan UMKM ini sangat mendukung bagi penyediaan lapangan kerja pada wilayah lokal (desa maupun kecamatan), bahkan berperanan sebagai pendukung perkembangan sektor wisata bendungan Selorejo.

Selain mampu menyerap banyak tenaga kerja, UMKM juga memiliki ketangguhan yang sudah teruji dengan baik dalam berbagi kondisi fluktuasi ekonomi. Ketika krisis ekonomi memporakporandakan tatanan perekonomian nasional, UMKM ini tetap dapat dapat bertahan bahkan berkembang lebih maju. Indikasi tentang daya tahan UMKM dapat dilihat dari jangka waktu usaha yang ditekuni oleh para pengusaha di sektor ini. Gambaran selengkapnya tentang jangka waktu menekuni usaha ini dapat dilihat pada diagram 3 . 


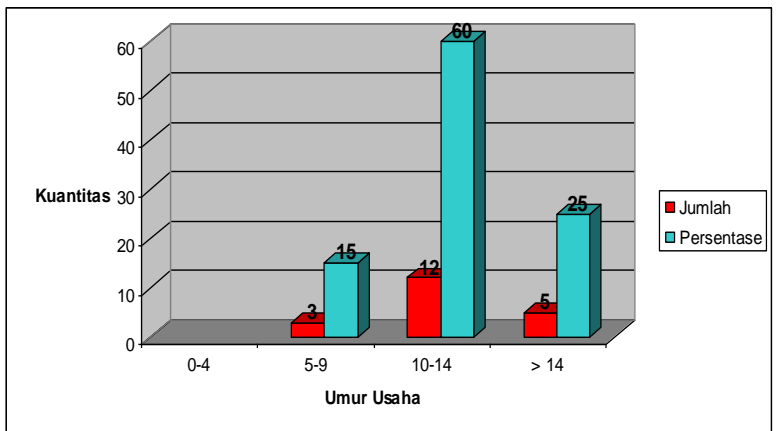

Sumber: Data pra survey, Januari 2014

Diagram 3. Umur Usaha

Dari data pada diagram 3 menunjukkan bahwa kelangsungan bisnis UMKM sebagian besar $(60 \%)$ 10-14 tahun. Hal ini berarti bahwa UMKM ini sudah teruji ketangguhannya dalam menghadapi berbagai kondisi fluktuasi ekonomi yang pernah terjadi di Indonesia. Ketangguhan dalam menghadapi berbagai kondisi perekonomian menunjukkan bahwa sektor ini sebenarnya layak untuk menjadi pilihan sandaran mata pencaharian bagi penduduk desa Kaumrejo dan sekitarnya.

Selain itu, UMKM Warung merupakan unit usaha yang menempati satu kawasan sentra perdagangan di bendungan Selorejo Kecamatan Ngantang Kabupaten Malang dan kegiatan usaha ini sudah menjadi "tradisi" bisnis bagi sebagian besar penduduk setempat sehingga mayoritas penduduk mengandalkan sektor ini sebagai mata pencahariannya. Hal ini menjadi dasar penentuan pemilihan UMKM sebagai mitra kerja IbM. Selain itu, pertimbangan lainnya adalah:

1. Lokasi UMKM berada dalam sentra usaha Mikro kecil dalam jenis usaha yang relatif homogen (warung) dan menempati lokasi yang sama sehingga dapat lebih fokus dalam melakukan pembinaan.

2. UMKM ini banyak menyerap tenaga kerja dari masyarakat yang berdomisili di desa Kaumrejo dan sekitarnya.

3. UMKM ini mempunyai mata rantai dengan nelayan ikan air tawar yang ada di lokasi tersebut serta menjadi salah satu daya tarik pariwisata bendungan Selorejo.

4. UKMK ini mudah dijangkau karena lokasinya berjarak relatif dekat, yakni kurang lebih $40 \mathrm{Km}$ dari Uniga.

5. UMKM ini mempunyai prospek usaha yang cukup baik, mengingat pada lokasi usaha berada dalam kawasan wisata yang terkenal di Jawa Timur sehingga pengunjung relatif banyak terutama pada hari-hari libur sekolah maupun libur kerja.

6. UMKM ini masih memerlukan penguatan dari sisi kapasitas manajerial, utamanya bidang pemasaran, layanan prima pada pelangan dan akuntansi.

\section{PERMASALAHAN}

Keberadaan UMKM Warung ini secara nyata memang mampu berkontribusi terhadap laju pertumbuhan ekonomi lokal (Desa Kaumrejo, namun bukan berarti kelompok usaha ini terbebas dari kendala dalam pengelolaannya. Achmadi (1995) menjelaskan bahwa kondisi umum yang dihadapi oleh kebanyakan kelompok usaha seperti ini adalah masih saja berkisar pada sistem pengelolaan yang masih tradisional, memiliki keterbatasan modal, akses pasar, dan manajemen keuangan.

Kondisi yang tidak menguntungkan tersebut diperparah dengan belum adanya profesionalitas dalam pengelolaan usaha yang antara lain nampak dari belum adanya standarisasi layanan kepada konsumen, standarisasi produk yang dijual, pengelolaan keuangan yang belum dilakukan secara benar, serta sistem pengelolaan usaha yang cenderung mewarisi pengelola sebelumnya. Dengan kata lain sistem pengelolaan usaha masih perlu untuk ditata lebih baik melalui peningkatan kualitas pengelolanya agar kinerja UMKM dapat lebih dioptimalkan. Adapun gambaran bagaimana tentang tata kelola usaha yang selama ini dilakukan oleh UMKM sampel dapat dilihat pada diagram 4 berikut ini.

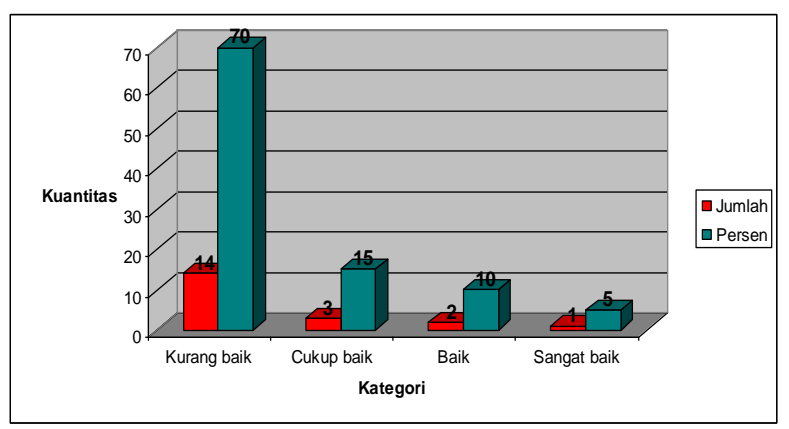

Sumber: Data pra survey, Januari 2014

Diagram 4. Tatakelola Warung

Diagram 4 menunjukkan bahwa dari sejumlah 20 usaha UMKM terdapat 14 unit usaha warung (70\%) termasuk dalam kategori kurang baik dalam pengelolaan usaha, utamanya dalam bidang tatakelola keuangan dan standarisasi layanan kepada konsumen; dan hanya 3 unit usaha (15\%) dari total sampel yang mengelola usaha termasuk dalam kategori "baik-sangat baik".

Pendapat yang dikemukakan oleh sebagian besar responden mengenai mengapa mereka melakukan sistem pengelolaan usaha yang kurang baik adalah minimnya pengetahuan dan ketrampilan tentang tata kelola usaha yang benar seperti: pencatatan dalam setiap transaksi, pembukuan untuk me- 
misahkan antara keuangan rumah tangga dengan keuangan bisnis, pemberian layanan yang memuaskan konsumen, pendapat yang mengemukakan bahwa mereka tidak mengelola secara baik karena tidak sempat dan memandang tidak penting melakukan aktivitas tersebut.

Gambaran tersebut menunjukkan bahwa UMKM warung masih belum sepenuhnya melaksanakan prinsip-prinsip tata kelola usaha yang baik dibidang keuangan/pembukuan usaha, layanan prima pada konsumen dan standarisasi produk dan layanannya. Selama ini, pengelolaan usaha mulai dari menyiapkan dan melakukan proses produksi (memasak), belanja bahan baku, melayani konsumen, pengelolaan keuangan dan keseluruhan proses kerja usaha dilaksanakan secara one man show oleh pemilik usaha.

Kondisi kurang menguntungkan tersebut masih diperparah dengan belum adanya profesionalitas dalam pengelolaan usaha, sistem keuangan yang masih belum memisahkan antara harta pribadi dengan harta usaha. Selain itu pelayanan kepada konsumen juga masih perlu ditingkatkan. Dengan demikian, masalah-masalah yang masih dihadapi oleh UMKM Warung Wisata Selorejo sampai saat ini antara lain:

1. Belum mempunyai kemampuan dalam bidang pembukuan

2. Belum memiliki pengetahuan dan ketrampilan tentang pelayanan prima kepada konsumen

3. Belum adanya standarisasi layanan kepada konsumen

4. Belum melaksanakan pembukuan usaha

5. Belum menerapkan prinsip-prinsip pelayanan prima pada konsumen.

Untuk itu melalui kegiatan IbM ini, diharapkan sebagian permasalahan utama yang dihadapi oleh UMKM calon mitra IbM bisa dicarikan jalan keluarnya secara baik.

\section{METODE PELAKSANAAN}

Dengan memperhatikan karakteristik UMKM Warung Wisata Selorejo yang nantinya menjadi mitra kerja serta permasalahan yang dihadapi, maka metode pendekatan yang akan dilakukan adalah perpaduan antara pelatihan dan bantuan peralatan pendukung serta pendampingan. Implementasi pendekatan tersebut dilakukan melalui tahapan-tahapan sebagai berikut:

1. Untuk dapat melaksanakan kegiatan ini secara optimal, maka langkah persiapan dialakukan oleh Tim pada tanggal 5 dan 6 Maret 2015. Pada tahap persiapan team leader memberikan penjelasan atas subtansi kegiatan $\mathrm{IbM}$ bagi peng- usaha warung dan melakukan serangkaian langkah operasionalisasi tugas pokok dan fungsi pada masing-masing individu dalam tim dengan harapan kegiatan berjalan sesuai dengan target.

2. Selanjutnya pada tangal 10 Maret 2015, tim melaksanakan Pra-Survey kelokasi mitra kerja di Kawasan wisata Selorejo Kabupaten Malang. Kegiatan ini dimaksudkan untuk menggali informasi secara mendalam tentang kondisi yang sedang dihadapi IbM mitra kerja terkait dengan pengelolaan usaha khususnya di bidang pengelolaan keuangan, sistem pemasaran dan tatacara pelayanan konsumen. Hasil pra-survey ini dijadikan rujukan dalam menyusun modul pelatihan serta merumuskan metoda pendekatan yang tepat dalam pelaksanaan pelatihan dan pendampingan agar agar hal itu dapat berjalan efektif dan efisien.

Berikut ini gambar photo 1 menunjukkan kegiatan pada saat kunjungan survey pendahuluan guna menggali informasi mendalam tentang kebutuhan ketrampilan bagi tata kelola usaha yang baik bagi pengelola Warung Wisata Selorejo.

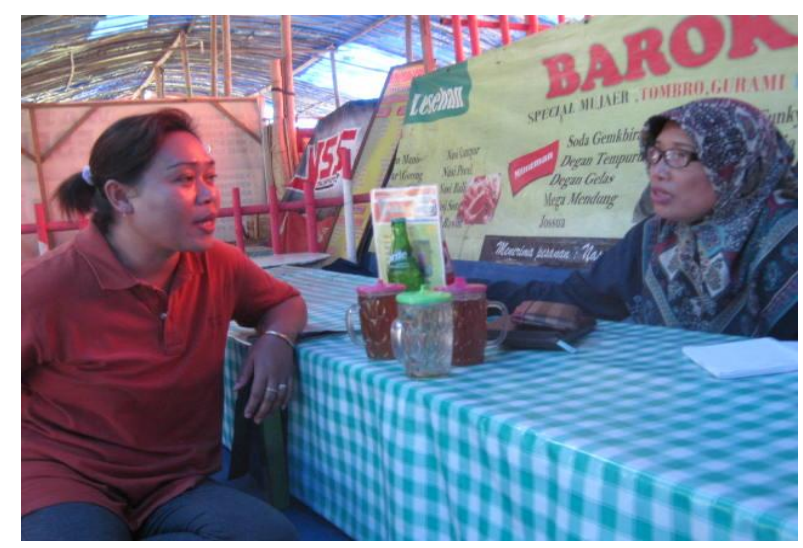

Photo 1. Survey Pendahuluan

3. Setelah pelaksanaan Pra Survey, tepatnya pada tanggal 12 dan 13 Maret 2015, tim melakukan diskusi dan koordinasi untuk menusun materi modul yang akan dijadikan panduan pelatihan. Dasar perumusan materi modul adalah informasi yang diperoleh dari hasil pengamatan maupun wawancara mendalam dengan mitra kerja IbM. Modul ini dirancang sesuai dengan kebutuhan mitra kerja dengan format subtansi yang sederhana dan mudah dipahami. Modul ini merupakan acuan bagi mitra kerja $\mathrm{IbM}$ dalam memahami dan mengaplikasikan materi pelatihan. Oleh karena itu, modul disusun sesederhana mungkin agar mudah dipahami dan dimplementasikan oleh mitra IbM. Adapun isi modul pelatihan (terlampir) meliputi: akuntansi; etos kewirausahaan; pemasaran; pelayanan prima pada konsumen, dan standarisasi pelayanan. 
4. Hasil pelatihan selanjutnya perlu dipraktekkan oleh mitra kerja dalam pengelolaan usahanya. Untuk mendukung efektifitas implementasi, maka materi pelatihan dilengkapi dengan contoh penerapannya sehingga memudahkan bagi peserta binaan menerapkan secara mandiri.

5. Guna medukung optimalisasi praktek materi pelatihan dan meningkatkan kinerja usaha, maka perlu diberikan bantuan dana stimulan produktif sesuai dengan kebutuhan. Bantuan stimulan ini dirasa sangan penting karena semenjak terkena bencana letusan gunung kelud, UMKM warung mengalami kelambanan dan bahkan kemacetan usaha, misalnya tidak sulit ditemukan adanya pelaku usaha warung yang setiap harinya mengalami kerugian atau hanya sekedar bertahan hidup saja selama kurang lebih 1 tahun. Bantuan stimulan ini diberikan kepada 5 orang dengan jumlah bantuan keseluruhannya sebesar Rp.7.000.000,-.

6. Langkah berikutnya adalah pendampingan. Kegiatan ini merupakan tindak lanjut dari pelatihan. Pendampingan ini perlu dilakukan agar UMKM mitra kerja dapat mengaplikasikan materi pelatihan secara benar. Kegiatan pendampingan ini sekaligus merupakan sarana kegiatan konsultasi, monitoring dan evaluasi. Kegiatan ini dilakukan dalam bentuk kunjungan rutin minimal dua minggu sekali sebagai sarana konsultasi dan evaluasi kemampuan mitra kerja, yaitu pelaku usaha warung, dalam menerapkan materi pelatihan. Konsultasi dan pemantauan perkembangan mitra kerja juga dilakukan melalui komunikasi telepon/SMS. Melalui pendampingan yang intensif diharapkan implementasi materi pelatihan dapat dilakukan oleh mitra kerja IbM secara optimal, sehingga peningkatan kinerja usahanya dapat dicapai.

Urutan langkah di atas tidaklah bersifat mutlak. Beberapa langkah dapat dilakukan secara simultan disesuaikan dengan perkembangan di lapangan.

\section{HASIL PELAKSANAAN}

\section{Profil Usaha Mikro Kecil Warung (Rumah Makan)}

Usaha warung makanan di kawasan wisata Selorejo mulai dirintis oleh beberapa orang pada tahun 1975. Selain sebagai tempat wisata, kawasan Selorejo juga memiliki bendungan yang dimanfaatkan sebagai tempat budi daya ikan air tawar. Ketersediaan ikan yang cukup banyak ini merupakan penunjang utama pendirian warung dengan ciri khas menyediakan menu ikan air tawar, utamanya ikan mujair, bagi para wisatawan. Pada awal pendirian usahanya, warung yang merupakan UMKM mitra kerja ini, melakukan aktivitas usaha- nya secara mandiri. Namun dengan berkembangnya usaha mereka, pada tahun 2015, pemilik warung mempekerjakan karyawan.

Seiring dengan pengalaman mengelola dan peningkatan usaha, maka mulai tahun 2000 usaha ini tidak hanya menyediakan makanan bagi konsumen yang berkunjung kekawasan wisata Selorejo saja, melainkan juga menyediakan jasa catering dan penjualan ikan air tawar. Untuk jasa catering biasanya melayani pesanan dari instansi pemerintah maupun swasta di wilayah Malang Raya. Sedangkan wilayah pemasaran penjualan ikan air tawar, seperti mujair, wader, dan udang, sudah menjangkau kebeberapa restoran di Surabaya.

Setelah beroperasi selama hampir 35 tahun, secara tidak terduga kawasan UMKM warung Selorejo terkena dampak langsung letusan Gunung Kelud. Akibat kejadian tersebut, maka lokasi usaha mereka mengalami rusak berat dan terpaksa harus berpindah lokasi untuk sementara waktu ke area baru yang berjarak 100 meter dari lokasi sebelumnya. Perpindahan lokasi usaha ini ternyata berdampak pada penurunan omset penjualan mereka dari rata-rata pemasukan $\mathrm{Rp} 3.000 .000,00$ menjadi Rp. 1.750.000,00 per minggu. Menurut mereka, penurunan omset ini disebabkan oleh: lokasi usaha kurang strategis, fasilitas pendukung kurang baik, serta kondisi warung tidak tertata baik.

\section{DISKRIPSI PELAKSANAAN}

Tahapan lanjutan yang akan dilaksanakan oleh tim IbM adalah melakukan pelatihan yang diselenggarakan pada tanggal 18, 25 Maret dan 1 April 2015. Penentuan jadwal pelaksanaaan pelatihan tersebut berdasarkan kesepakatan UMKM mitra kerja IbM dengan tim pelaksana. Setelah tahapan pelatihan dilaksanakan, maka tahapan berikutnya adalah melakukan pendampingan kepada mitra kerja yang pelaksanaannya dimulai pada minggu keempat bulan April sampai dengan Minggu ketiga bulan Oktober 2015. Kegiatan pendampingan dilakukan dalam bentuk kunjungan lapang oleh Tim Ibm dan instruktur dengan maksud melakukan monitoring maupun pemanduan dalam mengimplementasikan materi pelatihan. Tahap ini tidak sebatas pada kunjungan saja, karena tim IbM juga membuka akses komunikasi seluas mungkin melalui telephon dan SMS bilamana dalam pengimplementasian materi pelatihan tersebut, mitra kerja memerlukan panduan. Kegiatan pelatihan dilaksanakan di lokasi tempat usaha UMKM mitra kerja, yaitu di Kawasan Wisata Selorejo, Kabupaten Malang. Kegiatan pelatihan dapat dilihat pada gambar Photo 2. Pilihan lokasi ini sesuai kesepakatan dengan pihak mitra kerja agar pelaksanaan pelatihan bisa berlangsung secara efektif dan efisien. 


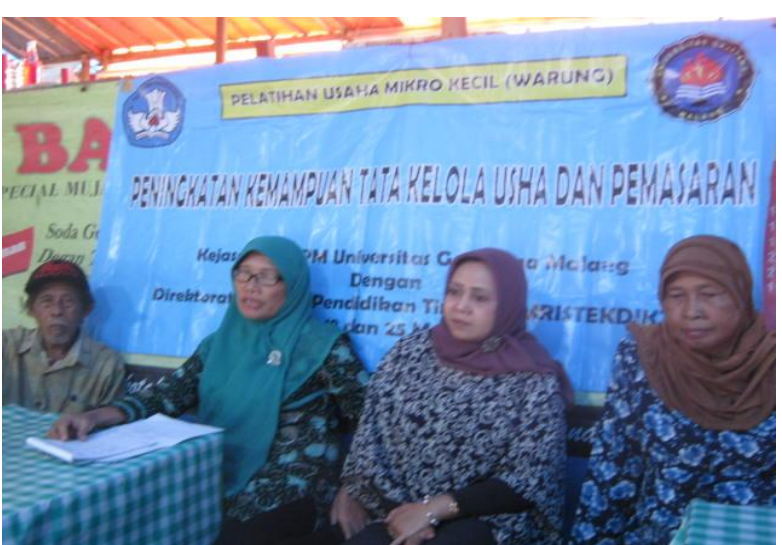

Photo 2. Ketika Pelatihan Berlangsung

\section{Tatakelola Keuangan}

Mengubah kebiasaan, sikap dan perilaku memang bukan pekerjaan mudah dan memerlukan waktu yang relatif lama. Meskipun sudah dilakukan pelatihan tentang perlunya tertib administrasi dan akuntansi disertai dengan penjelasan tentang manfaat yang diperoleh jika melaksanakannya, bukan berarti peserta binaan secara cepat bisa mengadaptasikan metode pembukuannya dengan materi tersebut. Hal ini nampak dari hasil monitoring dan evaluasi pada bulan April minggu ketiga, yang menunjukkan bahwa kedisiplinan dalam melakukan pencatatan keuangan telah mengalami kemajuan dibandingkan dengan saat pendampingan pada Minggu kedua bulan Mei 2015. Sebagian pelaku UMKM warung telah melaksanakan pencatatan aliran keuangan secara benar. Dalam hal tertib akuntansi ini, mitra kerja IbM digolongkan menjadi 4 kategori, yakni: sangat baik, baik, cukup baik dan kurang baik. Gambaran selengkapnya tentang tertib akuntansi yang dilaksanakan oleh mitra kerja IbM dapat dilihat pada Tabel 1.

Tabel 1. Implementasi Akuntansi

\begin{tabular}{|c|c|c|}
\hline Kategori & Jumlah & Persentase \\
\hline Sangat Baik & 1 & 20 \\
\hline Baik & 2 & 40 \\
\hline Cukup Baik & 2 & 40 \\
\hline Kurang Baik & . & . \\
\hline
\end{tabular}

Dari data tabel 1 dapat diketahui, bahwa terdapat kemajuan dalam bidang pencatatan usaha yang dilakukan oleh UMKM Warung Wisata, dibandingkan dengan pada saat dilakukan survey pendahuluan. Data pada tabel 1 menunjukkan bahwa semua UMKM Warung telah melaksanakan pencatatan dalam setiap penggunaan uang yang terkait dengan aktivitas usahanya. Namun demikian kategori perilaku tertib akuntansi pada mereka berbeda satu dengan yang lainnya; yakni sebanyak 40 persen masuk dalam kategori cukup baik dan baik, serta sebanyak 20 persen masuk dalam kategori sangat baik. Gambaran tersebut tersebut menunjukkan bahwa materi akuntansi yang diperoleh pada saat pelatihan telah dilaksanakan dalam praktik usaha, meskipun masih belum sesuai dengan yang diharapkan.

\section{Pelayanan pada Konsumen}

Pelayanan merupakan upaya untuk memelihara dan mempertahankan pelanggan dan menambah pelanggan baru. Banyak aspek yang perlu diperhitungkan dalam memberikan kepuasan pada pelanggan karena itu bukan hanya sekedar memberikan yang terbaik kepada pelanggan. Dalam persaingan usaha yang ketat seperti saat ini, kebanyakan pelaku usaha hanya menawarkan barang-barang yang bermutu saja. Mereka tidak memperhatikan hubungan baik dan berkesinambungan dengan para pelanggan. Dalam hal ini, pelayanan prima bukan hanya sekedar memberikan suatu layanan melainkan memerlukan sedikit pelayanan ekstra sesuai dengan harapan pelanggan.

Kualitas pelayanan suatu bisnis berperan penting dalam merangkul konsumen untuk melakukan pembelian. Kualitas pelayanan yang memuaskan akan mendorong konsumen untuk membeli produk yang bersangkutan ataupun untuk melakukan pembelian ulang. Jika perusahaan mampu memberikan pelayanan yang baik secara langsung atau tidak langsung, citra layanannya akan tersebar luas karena kepuasan yang dirasakan pelanggannya akan disampaikan oleh pelanggan yang satu ke pelanggan lainnya secara berantai.

Hasil monitoring dan evaluasi terhadap mitra kerja IbM menunjukkan bahwa metode pelayanan terhadap konsumen mengalami kemajuan yang pesat. Hal ini nampak dari cara mereka melayani konsumen yang akan membeli di warung mereka. Kecepatan pelayanan, keramahan menyapa konsumen dan prilaku saat menghadapi komplain dari konsumen menunjukkan penghargaan kepada konsumen. Pengusaha menyadari benar bahwa konsumen sangat menentukan kelangsungan usaha mereka. Adapun kategori prilaku layanan mereka kepada konsumen dapat dibagi menjadi kurang baik, cukup baik, baik dan sangat baik. Sampai dengan pendampingan bulan 4 bulan Oktober, perilaku UMKM dalam melaksanakan layanan kepada konsumen yang disajikan dalam Tabel 2.

Tabel 2. Pelayanan Konsumen

\begin{tabular}{lcc}
\hline Kategori & Jumlah & Persentase \\
\hline Sangat Baik & 2 & 40 \\
Baik & 2 & 40 \\
Cukup Baik & 1 & 20 \\
Kurang Baik & - & - \\
\hline
\end{tabular}


Dari data tabel 2 dapat diketahui, bahwa terdapat kemajuan dalam bidang layanan konsumen oleh UMKM Warung Wisata, dibandingkan dengan pada saat dilakukan survey pendahuluan. Data di atas menunjukkan bahwa selama kurun waktu 7 bulan pelaksanaan Ibm terdapat peningkatan yang signifikan atas kualitas layanan UMKM terhadap konsumen. Semua UMKM warung telah melaksanakan layanan konsumen; hanya saja kategori perilaku kualitas layanan mereka terhadap konsumen bervariasi. Sebanyak 40\%, kualias layanan mereka termasuk dalam kategori baik dan sangat baik. Sebanyak 20\% termasuk dalam kategori cukup baik. Ini menunjukkan bahwa materi standar layanan pada konsumen yang diperoleh pada saat pelatihan telah dilaksanakan dalam praktik usaha, meskipun masih belum semuanya melakukan standar kualitas layanan prima sebagaimana yang diharapkan.

\section{PEMBAHASAN}

Sebagaimana telah dikemukakan pada paparan sebelumnya, pelaksanaan pengabdian kepada masyarakat skema Ipteks bagi Masyarakat (IbM) bagi UMKM warung ini diharapkan dapat meningkatkan kinerja pengelola utamanya dalam tata kelola keuangan dan pelayanan kepada konsumen. Untuk dapat membuahkan hasil yang diharapkan, kegiatan IbM ini memerlukan rangkaian kegiatan yang disusun secara sistematis baik metode pelatihan, materi yang disampaikan maupun metode pendampingannya. Ketiga rangkaian kegiatan tersebut perlu disesuaikan dengan kondisi obyektif yang selaras dengan kebutuhan mitra kerja agar mudah dipahami dan diimplementasikan.

Pada tahap awal pelaksanaan pelatihan, intruktur menyampaikan tentang urgensi dan manfaat pelatihan bagi upaya memperbaiki tatakelola usaha. Penjelasan awal ini dipandang penting untuk membuka wawasan berpikir mitra kerja yang selama ini terbiasa mengelola usaha dengan sistem tradisional. Pada tahap ini peserta sudah respons positif seperti yang terlihat dalam kesungguhan mereka mengikuti seluruh sesi pelatihan. Mereka menjadi pembelajar aktif yang secara antusias mengikuti proses pelatihan maupun pendampingan. Suasana pelatihan yang cukup kondusif ini sangat membantu instruktur untuk membangun komunikasi timbal balik dalam upaya memberikan penjelasan mendalam atas materi yang diberikan.

Dari sudut pandang normatif, aktivitas pelatihan seyogyanya dapat mengubah sistem berpikir dan perilaku individu peserta latihan, sepeti yang dikatakan oleh Dale (2003). Namun kenyataannya, bisa jadi hasil yang diperoleh berbeda. Perubahan sistem berpikir maupun prilaku perorangan peserta latihan terkadang bergerak agak lamban dan kurang sebangun dengan yang diharapkan. Kelambanan peserta dalam menginternalisasi materi pelatihan disebabkan ada kesenjangan pengetahuan dan pengalaman antara instruktur dengan peserta latihan. Peserta latihan lebih banyak bertumpu pada pengalaman empiris selama mengelola usaha, sementara instruktur terkadang terjebak pada aspek teoritis-normatif. Kesejangan tersebut muncul, bukan terletak pada kualitas SDM yang rendah, melainkan lebih pada kurangnya pengetahuan tentang manfaat tatakelola keuangan dan pelayanan yang baik pada konsumen. Pengusaha juga menyadari bahwa mengelola usaha secara professional sangat diperlukan bagi peningkatan kinerja bisnis ditengah persaingan yang ketat (Dessler, 2008). Pengusaha paham benar bahwa usaha warung yang dikelola menghadapi persaingan yang ketat. Oleh karena itu perlu ada komunikasi yang lancar dengan mitra kerja agar proses transformasi pengetahuan dan ketrampilan berlangsung efektif guna meningkatkan kemampuan pengelola warung.

Materi pelatihan yang agak lamban dipahami oleh mitra kerja IbM adalah akuntansi. Namun demikian, materi tersebut direspons secara aktif oleh peserta. Hal ini dikarenakan materi akuntansi merupakan pengetahuan baru yang membutuhkan ketrampilan khusus untuk dapat menerapkannya. Selain itu pengelola warung juga berpendapat bahwa akuntansi sangat dibutuhkan untuk memajukan pengelolaan usaha.

Upaya untuk membuat peserta pelatihan memahami penerapan materi bukanlah pekerjaan sederhana, sebab mereka sudah terbiasa menerapkan pengelolaan usaha secara tradisional yang telah terbukti berhasil. Oleh karena itu, dalam setiap kunjungan lapangan ataupun melalui kontak telepon, tim pelaksana IbM secara terus menerus berusaha memberikan panduan kepada mitra kerja UMKM atas materi yang belum dipahami.

Khusus untuk materi akuntansi, mitra kerja IbM merasa enggan untuk menerapkannya. Rasa enggan ini timbul karena mereka kurang disiplin dalam mencatat setiap transaksi yang dilakukan maupun mengarsip data keuangan. Mereka beranggapan bahwa pola lama saja sudah cukup memadai. Namun ini bisa diatasi dengan komunikasi aktif selama pelatihan maupun pendampingan. Jalinan komunikasi dua arah yang intensif ini ternyata banyak membantu efektivitas dalam mentransfer pengetahuan dan ketrampilan pada pengelola Warung. 
Pada tahap pendampingan, tim melaksanakannnya melalui 7 kali kunjungan ke lokasi mitra kerja. Pendampingan dengan kunjungan langsung ini bertujuan untuk memantau langsung perkembangan kemampuan mitra kerja dalam menerapkan materi pelatihan. Selama melakukan pendampingan, tim IbM memfokuskan pada tatacara penerapan materi yang belum dipahami, utamanya materi akuntansi. Materi ini memang memerlukan perhatian khusus selama pendampingan berlangsung sebab peserta pelatihan masih belum dapat menerapkannya secara optimal akibat keterbatasan waktu untuk mempelajarinya.

Upaya pelaksanaan IbM melalui pelatihan, pendampingan dan pemberian bantuan dana stimulan produktif kepada pengelola UMKM warung diharapkan dapat mengoptimalkan pengelolaan UKKM sehingga usaha mereka ini dapat berjalan dengan lebih baik. Hal ini sesuai pendapat Daft (2006), yang menjelaskan bahwa usaha yang dikelola dengan manajemen bisnis yang profesional mampu membuat suatu bisnis bertahan hidup, dan bahkan berkembang lebih maju.

\section{KESIMPULAN DAN SARAN}

\section{Kesimpulan}

Dari hasil kegiatan pengabdian kepada masyarakat skema IbM bagi UMKM warung yang telah dilaksanakan, dapat disimpulkan sebagai berikut:

1. UMKM warung wisata Selorejo merespons positif pelaksanaan kegiatan IbM ini. Hal ini ditunjukkan dengan keterlibatan mereka secara aktif selama pelaksanaan pelatihan dan bersedia untuk mengikuti seluruh tahapan pelatihan.

2. Selama masa monitoring, evaluasi dan konsultasi pada saat pendampingan, UMKM warung wisata Selorejo berpartisipasi secara aktif, seperti yang terlihat dalam kesediaan mereka untuk mengimplementasikan materi yang telah didapat pada saat pelatihan, serta keterbukaan mereka dalam mengungkapkan hambatan yang dihadapi ketika mereka mengimplementasikan materi tersebut.

3. Adanya peningkatan kinerja pengelola UMKM warung wisata Selorejo di bidang akuntansi dan pelayanan kepada konsumen yang cukup signifikan.

\section{Saran}

1. Agar pelaksanaan pengabdian kepada masyarakat bagi UMKM warung dapat mencapai sasaran, maka perlu pendekatan secara fleksibel; dalam artian metode pelatihan, jalinan komunikasi maupun metode pendampingan dikondisikan tidak terlalu formal serta ada kesediaan untuk menyesuaikan jadwal pelatihan maupun pendampingan dengan waktu luang mitra kerja.

2. Setelah pelatihan terhadap UMKM dilaksanakan, perlu ada tindak lanjut untuk melakukan pendampingan terhadap mereka agar mereka dapat secara konsisten melakukan tatakelola usaha yang baik.

3. Untuk melakukan pembinaan lanjutan terhadap UMKM Warung Selorejo, perlu dilakukan kajian awal yang mendalam guna menentukan skala prioritas materi maupun metode pembinaan yang sesuai untuk dilaksanakan.

4. Tim pelaksana hendaknya berperan sebagai fasilitator agar proses pelatihan maupun pendampingan kepada UMKM dapat berjalan efektif.

\section{DAFTAR PUSTAKA}

Achmadi, M. (1995). Aspek Pengembangan dan Permasalahan Usaha Kecil. Cetakan Pertama, Erlangga Jakarta.

Badan Pusat Statistik (https://www.bps.go.id)

Dinas Komunikasi dan Informatika Propinsi Java Timur. (2013). Serap 469.274 tenaga kerja, UMKM Kab Malang maju pesat. Ditelurusi dari http://kominfo.jatimprov.go.id/read/umum/ 33957

Dinas Koperasi, PKM Propinsi Jawa Timur. (2002). Laporan Pelaksanaan Program Pengembangan Koperasi, dan PKM di Jawa Timur tahun Anggaran 2001.

Dale, M. 2003. Developing Management Skill. (Terjemahan). Jakarta: Gramedia

Daft, R. L. (2006). Manajemen. Edisi 6. Jakarta: Salemba Empat

Dessler, G. (2008). Human Resource Management. $11^{\text {th }}$ Edition. Upper Saddle River: Pearson.

Dollinger, M. J. (1999). Entreprenuership Strategies and Resources. New Jersey: Prentice Hall Inc.

Tambunan, T. H. (2003). Usaha Kecil dan Menengah di Indonesia Beberaoa Isu Penting. Jakarta: Salemba Empat. 